\title{
Optimizing management of chronic obstructive pulmonary disease in the upcoming decade
}

This article was published in the following Dove Press journal:

International Journal of COPD

7 January 2010

Number of times this article has been viewed

\section{Richard Russell' \\ Antonio Anzueto ${ }^{2}$ \\ Idelle Weisman ${ }^{3}$}

'Department of Thoracic Medicine, National Heart and Lung Institute, Imperial College, London, UK; ${ }^{2}$ University of Texas Health Science Center at San Antonio, South Texas Veterans Health Care System, San Antonio, Texas, USA; ${ }^{3}$ Pfizer Inc, Medical Affairs, Respiratory, Primary Care Business Unit, New York, USA

Correspondence: Antonio Anzueto University of Texas Health Science Center at San Antonio, South Texas Veterans Health Care System, 7400 Merton Minter Blvd. (I I IE), San Antonio, TX 78229, USA

Tel + I 2106175256

Fax +I 2105676677

Email anzueto@uthcsa.edu
Abstract: Chronic obstructive pulmonary disease (COPD) is a leading cause of disability and mortality. Caring for patients with COPD, particularly those with advanced disease who experience frequent exacerbations, places a significant burden on health care budgets, and there is a global need to reduce the financial and personal burden of COPD. Evolving scientific evidence on the natural history and clinical course of COPD has fuelled a fundamental shift in our approach to the disease. The emergence of data highlighting the heterogeneity in rate of lung function decline has altered our perception of disease progression in COPD and our understanding of appropriate strategies for the management of stable disease. These data have demonstrated that early, effective, and prolonged bronchodilation has the potential to slow the rate of decline in lung function and to reduce the frequency of exacerbations that contribute to functional decline. The goals of therapy for COPD are no longer confined to controlling symptoms, reducing exacerbations, and maintaining quality of life, and slowing disease progression is now becoming an achievable aim. A challenge for the future will be to capitalize on these observations by improving the identification and diagnosis of patients with COPD early in the course of their disease, so that effective interventions can be introduced before the more advanced, disabling, and costly stages of the disease. Here we critically review emerging data that underpin the advances in our understanding of the clinical course and management of COPD, and evaluate both current and emerging pharmacologic options for effective maintenance treatment.

Keywords: COPD, chronic obstructive pulmonary disease, long-acting bronchodilator, early treatment

\section{Introduction}

Chronic obstructive pulmonary disease (COPD) is a leading cause of disability and death worldwide, with population prevalence rates of $5 \%-13 \% .^{1-3}$ Prevalence rates are related directly to tobacco smoking and indoor air pollution, and are expected to rise as smoking rates continue to increase, notably among women and in developing countries. ${ }^{1,4}$ By 2030, COPD is expected to represent the third leading cause of death in middle-income countries. ${ }^{4}$ In addition, COPD accounts for a significant proportion of health care budgets, with the majority of costs being attributed to hospitalizations for exacerbations. ${ }^{5}$ Thus, there is a global drive to improve COPD diagnosis and management to reduce personal and economic burden.

COPD is characterized by airflow limitation and inflammation, resulting in progressive decline in respiratory function and quality of life (QoL); patients with COPD face a significantly increased risk for premature death. ${ }^{6}$ The pathologic effects of COPD on the respiratory system are pervasive, affecting the proximal and peripheral airways, 
lung parenchyma, and pulmonary vasculature. ${ }^{7}$ The clinical course of COPD may be punctuated by exacerbations that can be life-threatening and associated with worsening outcomes, including increased mortality risk and resource utilization. ${ }^{8,9}$ Moreover, comorbid conditions such as cardiovascular disease, diabetes mellitus, and depression, as well as associated systemic consequences, including weight loss and muscle dysfunction due to inactivity and deconditioning, add considerably to the overall burden of disease. ${ }^{9,10}$

COPD is considered to be preventable and treatable, ${ }^{1}$ yet, despite its high prevalence and significant burden, it remains substantially underdiagnosed and undertreated. ${ }^{11,12}$ Undiagnosed early-stage patients, especially if they are symptomatic, are more likely to progress to a more severe form of COPD that impacts further on QoL and increases health care costs. ${ }^{12,13}$

In this article, we draw together the latest understanding of COPD and evaluate current and potential future approaches to long-term treatment.

\section{Methods}

A rigorous, directed approach was adopted to identify relevant published literature. PubMed.gov (http://www.ncbi.nlm.nih.gov/ sites/entrez) was searched using the following terms: "COPD" AND "burden, prevalence", "clinical course", "lung function decline", "progression", "exacerbation, recovery", "treatment guidelines", "early treatment”, "maintenance”, "GOLD”, "long-acting bronchodilator", "long-acting beta-agonist", "longacting anticholinergic", "muscarinic antagonist", and "inhaled corticosteroids". The search was limited to articles published in English. Given the volume of literature available relating to the etiology, pathophysiology, and management of COPD, key terms were restricted to publication titles as follows: "course", "decline”, "progression”, “exacerbation”, "guidelines”, “early”, "maintenance", "GOLD”, and "exacerbation".

Many national and international respiratory societies have developed guidelines for COPD management. ${ }^{1,14-16}$ Guideline discussion focuses principally on the internationally recognized Global Initiative for Chronic Obstructive Lung Disease (GOLD) guidelines, ${ }^{1}$ upon which many local guidelines are based.

The review of emerging treatment options focuses on pharmacotherapeutic agents recently approved or submitted to regulatory authorities for approval, including indacaterol and roflumilast. The long-acting anticholinergic aclidinium bromide is also discussed. PubMed.gov search terms for these agents were "COPD” AND "[drug name]".
Major respiratory congress abstract databases (American Thoracic Society and European Respiratory Society) were also searched from 2007 to 2009. Additional literature was identified by hand-searching reference listings of the publications identified using the approach outlined above.

\section{Evolving concepts of lung function decline}

The clinical course of COPD has been viewed as a progressive decline in lung function over time (measured in terms of forced expiratory volume in one second $\left.\left[\mathrm{FEV}_{1}\right]\right) .{ }^{17}$ However, recent work suggests that disease progression may not be uniform and that not all patients follow the same clinical course. Furthermore, in addition to smoking, other clinical factors, such as the presence of symptoms, are important in COPD progression.

Evidence from the Framingham cohort ${ }^{13}$ and large-scale interventional trials ${ }^{18,19}$ reinforce earlier work demonstrating that annual rates of decline not only differ according to smoking status ${ }^{17}$ but, importantly, also appear to be greater during the earlier disease stages. In light of these observations, the Framingham cohort authors have offered an alternative view of disease progression that highlights the heterogeneity of the rate of lung function decline in the context of smoking history (Figure 1 and accompanying table). ${ }^{13}$ In contrast with the Fletcher-Peto study, ${ }^{17}$ the Framingham population includes both men and women, a wide age range (13-71 years), and both working and nonworking participants. It also included close attention to symptoms and a longitudinal follow-up of 23 years. ${ }^{13}$ Although changes in lung function from adolescence to old age differ in males and females, analysis of the Framingham cohort revealed similar increases in the rate of $\mathrm{FEV}_{1}$ decline in both sexes, and beneficial effects of smoking cessation with age, notably among early quitters. ${ }^{13}$ Also noteworthy (and in contrast with the observations of Fletcher and Peto), ${ }^{17}$ symptomatic patients represented a susceptible group for progressive lung function decline, reinforcing current thinking that multidimensional influences impact COPD progression and that early diagnosis and intervention are critical. As such, COPD phenotyping and its impact on disease progression are areas of intense research. ${ }^{20-22}$ Symptom status also appeared to contribute to the rate of lung function decline among a cohort of 519 patients with GOLD Stage I disease at baseline (according to prebronchodilator spirometry), in that patients with symptomatic disease had a faster decline in $\mathrm{FEV}_{1}$, increased respiratory care utilization, and lower QoL compared with those with asymptomatic disease at baseline. ${ }^{23}$ 

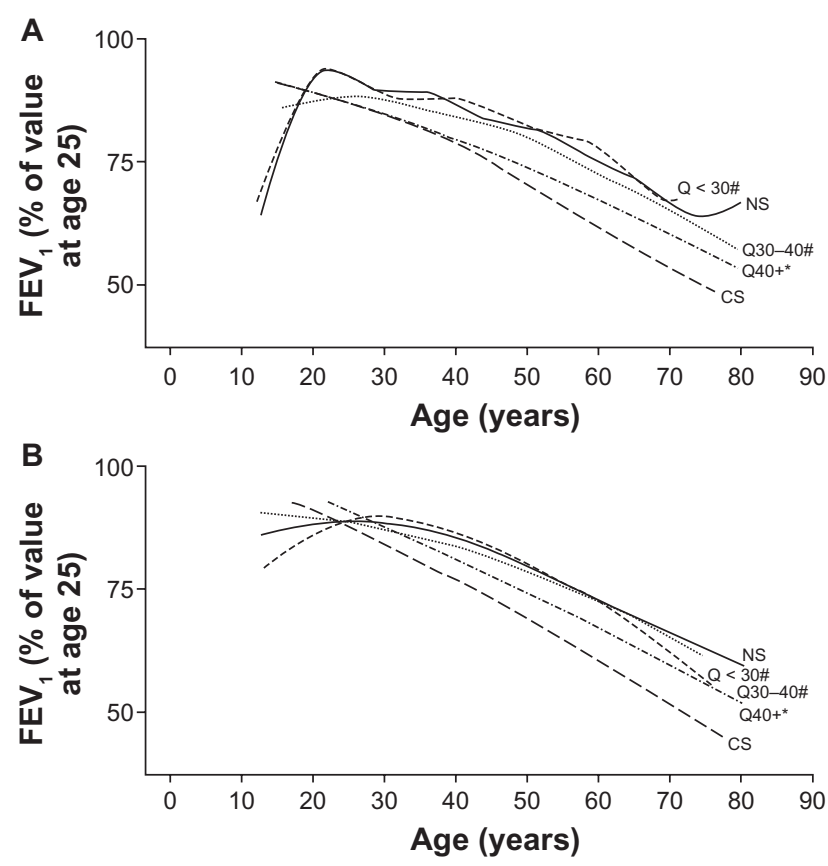

Figure I Effects of smoking and smoking cessation on decline in lung function among $\mathbf{A}$ male and $\mathbf{B}$ female adults with chronic obstructive lung disease. ${ }^{13}$

Notes: $* P<0.05$ versus healthy never-smokers; $\# P<0.05$ versus continuous smokers.

Abbreviations: NS, never smokers (solid line); CS, continuous smokers (dashed line, long); $\mathrm{Q}<30$, smokers who quit before the age of 30 years (dashed line, short); Q30-40, smokers who quit between the ages of 30 and 40 years (dotted line); Q40+, smokers who quit after the age of 40 years (dot-dash line). A prospective evaluation of lung function $\left(\mathrm{FEV}_{1}\right)$ over time (median follow-up 23 years) in the Framingham Offspring cohort with two or more spirometry measurements during follow-up $(n=4391)$ indicated marked differences in the rate of lung function decline according to smoking status. Panel A illustrates the decline in FEV, over time among men and Panel B illustrates the decline in FEV, over time among women.

\begin{tabular}{lll}
\hline $\begin{array}{l}\text { Age at smoking } \\
\text { cessation }\end{array}$ & Gender & FEV, decline $(\mathbf{9 5 \%} \mathbf{C I})$ \\
\hline$<30$ years & Male & $15.5(11.3-19.8)$ \\
& Female & $10.4(6.3-14.5)$ \\
$30-40$ years & Male & $24.0(20.0-28.1)$ \\
& Female & $16.5(14.0-19.0)$ \\
$>40$ years & Male & $28.9(26.1-31.1)$ \\
& Female & $21.0(18.8-23.2)$ \\
\hline
\end{tabular}

Abbreviations: $\mathrm{FEV}$, forced expiratory volume in I second; $\mathrm{Cl}$, confidence interval. Reprinted with permission of the American Thoracic Society. Copyright (C) American Thoracic Society. Kohansal R, Martinez-Camblor P, Agusti A, Buist AS, Mannino DM, Soriano JB. The natural history of chronic airflow obstruction revisited: an analysis of the Framingham offspring cohort. Am J Respir Crit Care Med. 2009;180:3-10. Official journal of the American Thoracic Society. ${ }^{13}$

These latter observations highlight the potential for early treatment intervention to relieve dyspnea and thereby maintain or even improve the capacity for physical activity, ${ }^{24}$ which has been shown to decline during the early disease stages. ${ }^{25}$ The need for early diagnosis to facilitate early interventions is further underscored by the close relationship between physical activity and clinical functional status. ${ }^{26}$ Among a cohort of 341 COPD patients hospitalized with a first exacerbation, higher levels of physical activity were associated with significantly higher diffusing capacity of the lung for carbon monoxide, expiratory muscle strength, six-minute walking distance, and maximal oxygen uptake. ${ }^{26}$ In addition, more physically active patients appeared to have reduced systemic inflammation. ${ }^{26}$ etc Taken together, these data suggest that early diagnosis and interventions to facilitate sustained physical activity could potentially slow disease progression.

\section{Role of exacerbations}

Exacerbation frequency appears to exert a negative impact on progressive lung function decline, at least in ex-smokers..$^{27,28}$ Among a cohort of 109 COPD patients, frequent exacerbators had a significantly faster decline in $\mathrm{FEV}_{1}(-40.1 \mathrm{~mL} /$ year $)$ and peak expiratory flow $(-2.9 \mathrm{~L} / \mathrm{min} /$ year $)$ compared with infrequent exacerbators $(-32.1 \mathrm{~mL} /$ year and $-0.7 \mathrm{~L} / \mathrm{min} /$ year, respectively). ${ }^{27}$ Similarly, in a separate study in 102 patients with COPD, the annual rate of decline in $\mathrm{FEV}_{1}$ was significantly higher among frequent versus infrequent exacerbators $(P=0.017) .{ }^{28}$

As COPD progresses, exacerbations become more frequent. ${ }^{27,29,30}$ Donaldson et al reported that patients with severe COPD (GOLD Stage III) had an annual exacerbation frequency of 3.43 compared with 2.68 for patients with moderate COPD (GOLD Stage II, $P=0.029$ ). ${ }^{27}$

Recent evidence also extends our knowledge of recovery following acute exacerbations. Patients experiencing an acute exacerbation remain at increased risk for subsequent exacerbations during the recovery phase, ${ }^{31}$ and are markedly inactive during and after hospitalization. ${ }^{32}$ Indeed, exacerbations tend to occur in clusters, and the two months following an initial exacerbation represent a high-risk period for subsequent exacerbations. ${ }^{33}$ Some patients also fail to regain their pre-exacerbation symptomatic status. ${ }^{31,34}$ Such patients appear to experience a persistently heightened inflammatory state. ${ }^{31,35}$ The rate of lung function decline for these patients has yet to be evaluated, although it has been shown that higher mortality rates are associated with exacerbations.

\section{Current approaches to managing COPD}

The internationally recognized GOLD guidelines were developed to increase awareness of COPD and to provide up-to-date information on management approaches. ${ }^{1}$ Several national guidelines have been issued and are in broad agreement with the GOLD guidelines. ${ }^{14-16}$ In the UK, National Institute for Health and Clinical Excellence (NICE) guidelines are currently being updated based on recent evidence of clinical and cost effectiveness of treatment options. 
Despite initiatives to improve detection and treatment of COPD, clinical guidelines are poorly implemented in both primary $^{36,37}$ and secondary care settings. ${ }^{36,38}$ Diagnosis is hampered by very limited use of spirometry within primary care because of lack of access and time, cost constraints, inaccurate interpretation of results, and inadequately trained staff. ${ }^{39,40}$ A recent study suggested only $30 \%$ of patients are diagnosed using spirometry according to guideline standards. ${ }^{41}$ Furthermore, evidence suggests that pharmacologic therapies are frequently prescribed inappropriately and not according to recommendations based on disease severity. ${ }^{18,42}$

\section{Current pharmacologic maintenance options}

GOLD guidelines advocate a patient-centered, stepwise approach to treatment, depending on disease severity (Figure 2). ${ }^{1}$ Intermittent symptoms can be treated with short-acting bronchodilators (SABAs). Several drug classes are approved for maintenance treatment (ie, medication taken regularly to improve symptoms not controlled by SABAs). These include anticholinergics (long-acting antimuscarinic antagonists [LAMAs]), long-acting $\beta_{2}$ agonists (LABAs), LABA-inhaled corticosteroid (ICS) combinations, methylxanthines (eg, theophylline), and SABAs and their combinations (Table 1). The latter (salbutamol [albuterol]) either alone or in combination with ipratropium is usually reserved for use as rescue medication.

LABAs and LAMAs are currently the preferred pharmacotherapeutic options for maintenance treatment, ${ }^{1}$ with bronchodilation achieved through different mechanisms (Table 1). Currently available long-acting inhaled bronchodilators are the once-daily LAMA, tiotropium, and the twice-daily LABAs, salmeterol and formoterol. The relative benefits of which agent to use first have not been systematically studied; however, tiotropium is widely used and has generally been shown to provide better bronchodilation and clinical outcomes than the twice-daily LABAs. ${ }^{43-46}$ Based on current evidence, initial treatment with an LAMA appears to be a rational approach, given its ability to reverse the heightened cholinergic tone that predominates in COPD patients. ${ }^{15}$ LABAs initiate an alternative pathway of bronchodilation. ${ }^{47}$ When symptoms are not controlled with monotherapy, adding an LABA to an LAMA "dual" long-acting bronchodilator therapy may be more effective than either agent alone, without increased side effects. ${ }^{46,48,49}$

ICS treatment is not recommended as monotherapy but can provide additional benefits, such as reduced exacerbation frequency, when combined with LABA therapy in patients with moderate and severe COPD and a history of COPD

\begin{tabular}{|c|c|c|c|}
\hline I: Mild & II: Moderate & III: Severe & IV: Very severe \\
\hline $\begin{array}{l}\mathrm{FEV}_{1} / \mathrm{FVC}<0.70 \\
\mathrm{FEV}_{1} \geq 80 \% \\
\text { predicted }\end{array}$ & $\begin{array}{l}\mathrm{FEV}_{1} / \mathrm{FVC}<0.70 \\
50 \% \leq \mathrm{FEV}_{1} \\
<80 \% \text { predicted }\end{array}$ & $\begin{array}{l}\mathrm{FEV}_{1} / \mathrm{FVC}<0.70 \\
30 \% \leq \mathrm{FEV}_{1} \\
<50 \% \text { predicted }\end{array}$ & $\begin{array}{l}\mathrm{FEV}_{1} / \mathrm{FVC}<0.70 \\
\mathrm{FEV}_{1}<30 \% \text { predicted, or } \\
\mathrm{FEV}_{1}<50 \% \text { predicted plus chronic } \\
\text { respiratory failure }\end{array}$ \\
\hline \multicolumn{4}{|c|}{$\begin{array}{l}\text { Active reduction of risk factor(s): influenza, pneumococcal vaccination } \\
\text { Add short-acting bronchodilator (when needed) }\end{array}$} \\
\hline & \multicolumn{3}{|c|}{$\begin{array}{l}\text { Add regular treatment with one or more long-acting bronchodilators } \\
\text { (when needed); add rehabilitation }\end{array}$} \\
\hline & & \multicolumn{2}{|c|}{$\begin{array}{l}\text { Add inhaled glucocorticosteroids if repeated } \\
\text { exacerbations }\end{array}$} \\
\hline & & & $\begin{array}{l}\text { Add long-term oxygen if chronic } \\
\text { respiratory failure. Consider surgical } \\
\text { treatment }\end{array}$ \\
\hline
\end{tabular}

Figure 2 The stepwise approach to the management of chronic obstructive lung disease.' 
Table I Current pharmacologic options for the management of COPD'

\begin{tabular}{|c|c|c|c|}
\hline Class & Agent/s & Mode of action & Clinical effect \\
\hline $\begin{array}{l}\text { Long-acting } \\
\beta_{2} \text {-agonist (LABA) }\end{array}$ & $\begin{array}{l}\text { Salmeterol } \\
\text { Formoterol }\end{array}$ & $\begin{array}{l}\text { - Stimulate } B_{2} \text {-adrenergic receptors } \\
\text { in airway smooth muscle } \\
\text { - Cause increased levels of cAMP } \\
\text { - Increase the rate of ciliary transport } \\
\text { of mucus } \\
\text { - Decreased mast cell degranulation }\end{array}$ & $\begin{array}{l}\text { - Bronchodilation by relaxing smooth } \\
\text { muscle and opening airways }\end{array}$ \\
\hline LAMA & Tiotropium & $\begin{array}{l}\text { - Inhibit muscarinic receptors } \\
\text { - Block the parasympathetic nervous system } \\
\text { - Reduce viscous mucus secretions } \\
\text { - Act on cholinergic tone, the only reversible } \\
\text { mechanism of COPD }\end{array}$ & $\begin{array}{l}\text { - Bronchodilation by reducing } \\
\text { contraction } \\
\text { of airway smooth muscle } \\
\text { - Reduce hyperinflation }\end{array}$ \\
\hline $\begin{array}{l}\text { Methylxanthines } \\
\text { (phosphodiesterase } \\
\text { inhibitors) }\end{array}$ & Theophylline & $\begin{array}{l}\text { - Phosphodiesterase inhibition } \\
\text { - Raised cAMP }\end{array}$ & - Limited use due to safety profile \\
\hline $\begin{array}{l}\text { LABA-ICS } \\
\text { combinations }\end{array}$ & $\begin{array}{l}\text { Formoterol- } \\
\text { budesonide } \\
\text { Salmeterol-fluticasone }\end{array}$ & $\begin{array}{l}\text { - As above plus ICS-associated } \\
\text { anti-inflammatory effects }\end{array}$ & $\begin{array}{l}\text { - Reduce risk of exacerbation in patients } \\
\text { with severe/very severe disease who } \\
\text { experience repeated exacerbations }\end{array}$ \\
\hline $\begin{array}{l}\text { Short-acting LABA-LAMA } \\
\text { combinations }\end{array}$ & $\begin{array}{l}\text { Fenoterol/ipratropium } \\
\text { Salbutamol (albuterol)- } \\
\text { ipratropium }\end{array}$ & - As above for long-acting agents & $\begin{array}{l}\text { - Only indicated as rescue medication } \\
\text { and not maintenance therapy } \\
\text { - May be associated with increased risk } \\
\text { of cardiovascular events }\end{array}$ \\
\hline
\end{tabular}

Abbreviations: cAMP, cyclic adenosine monophosphate; COPD, chronic obstructive pulmonary disease; LAMA, long-acting muscarinic antagonist; LABA, long-acting $\beta_{2}$-agonist; ICS, inhaled corticosteroids.

exacerbations. ${ }^{1,19,49}$ ICS-LABA combinations have been associated with increased risk of pneumonia, ${ }^{19,50,51}$ with some ICS formulations (fluticasone) putatively more likely to be associated with pneumonia than others (budesonide). ${ }^{48}$

LAMA plus LABA plus ICS "triple therapy" may have additional clinical benefits and achieve more optimal control in patients with severe COPD, reducing dyspnea and rescue medication use, ${ }^{52}$ providing greater improvements in lung function, ${ }^{48,52,53}$ reducing day- and night-time symptoms, ${ }^{48}$ improving QoL measures, ${ }^{53}$ and reducing exacerbations. ${ }^{48}$ Although triple therapy is often used in patients with severe and very severe COPD, there is limited evidence to support the long-term benefits over other combination therapy, and cost constraints may limit its use in clinical practice.

Methylxanthines, such as theophylline, are reserved as third-line options due to their side effect burden, and are only recommended for very severe disease. ${ }^{1}$ At low doses they may enhance the anti-inflammatory effects of corticosteroids ${ }^{54}$ and hence be useful in combination regimens. Long-term oral glucocorticosteroid therapy is not recommended, but may be necessary to treat exacerbations in patients with severe COPD. Patients with viscous sputum may benefit from mucolytic therapy, ${ }^{55}$ although the overall benefits seem small and routine use is not currently recommended. Other chronic therapies, such as antioxidants, carbocysteine, and
$\mathrm{N}$-acetylcysteine, may reduce COPD exacerbations, ${ }^{55-57}$ but evidence is conflicting. ${ }^{58}$

For inhaled drugs, delivery systems, correct use, and patient adherence are important considerations when selecting appropriate treatment for individual patients. Inspiratory flow rate is important for correct inhaler use, especially in patients with severe disease; patients should therefore have their technique checked regularly and their flow rate measured if necessary. Adherence to COPD therapies is poor and declines over time, ${ }^{59}$ which may in part be influenced by the inhaler device. At present, there are limited data to suggest an advantage for one type of inhaler over another for the drugs currently available, although devices that are complicated and require coordination between actuation and inhalation are less likely to be accepted and used effectively. ${ }^{60}$

\section{Nonpharmacologic treatment options}

Although optimal COPD management plans integrate both pharmacologic and nonpharmacologic interventions, full consideration of the latter is beyond the scope of this article. However, effective and evidence-based options, including smoking cessation programs, exercise, education, vaccination, pulmonary rehabilitation, and management of comorbidities should be considered and tailored to the individual. Endocrine derangements are common, as is 
cardiovascular disease. ${ }^{61,62}$ Pulmonary rehabilitation should be considered for all patients with COPD and may address particular problems, such as exercise deconditioning, relative social isolation, altered mood states (especially depression), muscle wasting, and weight loss, none of which are addressed adequately by current pharmacologic options. Influenza and pneumococcal vaccinations are recommended as an important risk reduction strategy. ${ }^{1}$

\section{New and emerging options for maintenance treatment}

The development of new respiratory medications continues and current research focuses on novel once-daily agents for administration either as monotherapy or in combination with other agents. These include the first once-daily LABA, indacaterol, the selective, once-daily, oral phosphodiesterase (PDE)-4 inhibitor, roflumilast, and the new, most probably twice-daily LAMA, aclidinium.

\section{Indacaterol}

Indacaterol was approved for use in the European Union in December 2009 for COPD maintenance treatment and, at the time of writing, is pending approval in the US. European approval was based on data from two pivotal Phase III studies which showed that indacaterol improved lung function (trough $\mathrm{FEV}_{1}$ ), dyspnea, QoL, and rescue medication use compared with placebo (Table 2). Further studies are in progress.

The INHANCE (Indacaterol Versus Tiotropium to Help Achieve New COPD Treatment Excellence) study was a 26-week evaluation of indacaterol $150 \mu \mathrm{g}$ and $300 \mu \mathrm{g}$ versus placebo and open-label tiotropium in 2059 patients with moderate-to-severe COPD. ${ }^{63}$ Indacaterol was noted to be suitable for once-daily dosing, and it was thought that it was likely to be "at least as effective as tiotropium for bronchodilation and other clinical outcomes such as dyspnea and health status". As the authors note, one of the limitations of the study was the open-label comparison, and this needs to be borne in mind when interpreting the study results. ${ }^{63}$

The INVOLVE (Indacaterol: Value in COPD Pulmonary Disease: Longer-term Validation of Efficacy and Safety) study was a 52 -week evaluation of indacaterol $300 \mu \mathrm{g}$ and $600 \mu \mathrm{g}$ versus placebo and formoterol $12 \mu \mathrm{g}$ in 1732 patients with moderate to severe COPD. ${ }^{64}$ Improvement in lung function was noted when compared with formoterol. "COPD worsening" was the most common adverse event in both studies across active treatment and placebo arms. ${ }^{63,64}$ No differences in mortality rates compared with placebo were reported in either study. ${ }^{63,64}$

\section{Roflumilast}

Roflumilast is unique among the PDE inhibitors, having selectivity for PDE-4 and no apparent inhibitory effect on PDE-3, which has been associated with cardiotoxicity for other agents in this class. ${ }^{65}$ Roflumilast is associated with reduced cellular inflammatory activity, and its therapeutic effects include bronchodilation, induction of cytokine and chemokine release from inflammatory cells, and inhibition of microvascular leakage and cellular trafficking. Clinical studies with roflumilast monotherapy demonstrated improved lung function, reduced moderate-to-severe exacerbations, reduced requirement for antiinflammatory/anti-infective medications, and improved QoL measures (Table 2). ${ }^{66,67}$ Similarly, improvements in lung function and exacerbation outcomes were reported when roflumilast was added to tiotropium, or to salmeterol plus fluticasone. ${ }^{68}$ Notable side effects with roflumilast include headache, weight loss (2.5 kg in all studies at six months and one year), diarrhea, nausea, and stomach ache (ie, gastrointestinal side effects that resulted in a significant early study withdrawal rate). ${ }^{66-68}$

Approvals for roflumilast are pending; however, it has been recommended for approval in Europe by the Committee for Medicinal Products for Human Use as maintenance treatment as an "add-on" to bronchodilator therapy in patients with severe COPD $\left(\mathrm{FEV}_{1}<50 \%\right.$ predicted) and a history of chronic sputum production and exacerbations. ${ }^{69}$

\section{Aclidinium}

Aclidinium is currently in an earlier stage of clinical development than indacaterol and roflumilast. To date, clinical studies have demonstrated a bronchodilatory effect and an improvement in QoL versus placebo in patients with moderate-to-severe COPD, and an acceptable tolerability profile. ${ }^{70}$ Preclinical studies suggest a potential for reduced class-related adverse effects with this agent, although confirmation from large-scale clinical trials is awaited.

A number of outstanding questions remain to be answered before the place of indacaterol, roflumilast, and aclidinium in current treatment strategies can be determined. The design of the INHANCE indacaterol study, in which tiotropium was given as open-label therapy, limits the conclusions that can be drawn from these data with regard to the relative efficacy of these agents, and additional data are required from studies that are well controlled. Tolerability issues with roflumilast may limit its use in some patients. ${ }^{66-68}$ 
Table 2 Emerging therapies for COPD

\begin{tabular}{l}
\hline Study \\
\hline Indacaterol \\
\hline INHANCE \\
26 weeks, indacaterol I $50 \mu \mathrm{g}$ and \\
$300 \mu \mathrm{g}$ versus placebo and open-label \\
tiotropium in moderate-to-severe \\
COPD \\
( $\mathrm{n}=2059 ; 77 \%$ completed study)
\end{tabular}

( $n=2059 ; 77 \%$ completed study)

\section{INVOLVE}

52 weeks, indacaterol $300 \mu \mathrm{g}$ and $600 \mu \mathrm{g}$ versus placebo and formoterol $12 \mu \mathrm{g}$ in moderate-to-severe COPD ( $n=1732 ; 74 \%$ completed study)

\section{Roflumilast}

M2-124 and MI-125

52 weeks, identical studies performed in 10 and 8 countries, respectively. Assessed roflumilast $500 \mu \mathrm{g}$ once daily versus placebo in symptomatic moderate-to-severe COPD (total $\mathrm{n}=3091$ )

M2-127

24 weeks, roflumilast $500 \mu \mathrm{g}$ or placebo plus salmeterol in moderateto-severe COPD (total $\mathrm{n}=$ 933)

\section{M2-128}

24 weeks, roflumilast $500 \mu \mathrm{g}$ or placebo plus tiotropium in moderate-to-severe symptomatic COPD (total $\mathrm{n}=933$ )
Efficacy findings Safety findings

Reference(s)
Indacaterol improved FEV , dyspnea, and quality of life, and reduced use of rescue medications, and exacerbations versus placebo Noninferiority to tiotropium
Indacaterol improved FEV , dyspnea, day and night symptoms, QoL, delayed time to exacerbation, and reduced use of rescue medications
Combined results of M2-124 and M2-125:

Roflumilast improved FEV , dyspnea, and reduced exacerbations; there were no differences in QoL

Salmeterol + roflumilast versus salmeterol + placebo Addition of roflumilast improved $\mathrm{FEV}_{\text {, }}$ and reduced the frequency differences in dyspnea, QoL, or rescue medication use

Tiotropium + roflumilast versus tiotropium + placebo Addition of roflumilast improved $\mathrm{FEV}_{\text {, }}$, QoL, and dyspnea and reduced rescue medication use. There were no reductions in exacerbations of exacerbations. There were no
Adverse events: Similar incidences in all treatment groups (64\%-67\%); most common were COPD worsening (18\%-22\%) and upper RTI (7\%-8\%). Higher incidence of cough occurring within five minutes of indacaterol administration ( $17 \%-21 \%$ versus $0.8 \%$ and $2.4 \%$ for tiotropium and placebo, respectively). This did not increase study discontinuation rates, and cough as an adverse event did not differ across treatment groups. Mortality: Three deaths (indacaterol $\mathrm{I} 50 \mu \mathrm{g}, \mathrm{n}=\mathrm{I}$; tiotropium, $\mathrm{n}=2$ ), none related to treatment

Adverse events: Similar incidences among treatment groups $(62 \%-71 \%)$; most common (occurring $>10 \%$ patients) were COPD worsening (28\%-35\%) and nasopharyngitis (13\%-19\%). Higher incidence of cough occurring within five minutes of indacaterol administration ( $19 \%$ versus $0.8 \%$ and $1.8 \%$ for formoterol and placebo, respectively). This did not increase study discontinuation rates.

Mortality: Eight deaths during treatment (indacaterol $350 \mu \mathrm{g}, \mathrm{n}=\mathrm{l}$; formoterol, $n=3$; placebo, $n=4$ ); the indacaterol death (cardiac arrest) suspected to be related to treatment (patient discontinued due to dyspnea).

Adverse events: Higher rate with roflumilast versus placebo

(67\% versus $62 \%$ )

Greater weight loss observed with roflumilast.

Mortality: Similar rates between treatment arms ( $2 \%$ in both) nausea were more frequently observed in salmeterol + roflumilast group Withdrawals: More withdrawals occurred in the salmeterol + roflumilast versus salmeterol + placebo group

Adverse events: Weight loss, diarrhea, and nausea were more frequently observed in tiotropium + roflumilast group
Adverse events: Weight loss, diarrhea, and Fabbri et al ${ }^{68}$

Dahl et $\mathrm{al}^{64}$

Calverley et al ${ }^{16}$

Fabbri et $\mathrm{al}^{68}$
Abbreviations: COPD, chronic obstructive pulmonary disease; $\mathrm{FEV}_{1}$, forced expiratory volume in one second; RTI, respiratory tract infection; QoL, quality of life.

submit your manuscript | www.dovepress.com 


\section{Moving forward: advances in optimal management}

COPD is a chronic illness requiring long-term treatment. The clinical aim of maintenance therapy focuses on controlling symptoms and reducing exacerbation frequency. ${ }^{1}$ Recent data suggest that maintenance bronchodilator therapy may contribute to slowing the rate of lung function decline in symptomatic patients with COPD, raising the potential for disease-course modification through ongoing pharmacotherapy.

The first suggestion that long-term bronchodilator therapy might slow $\mathrm{FEV}_{1}$ decline in COPD patients came from a post hoc analysis of 12-month data from two double-blind, randomized, placebo-controlled tiotropium trials. ${ }^{71}$ The mean annual decline in $\mathrm{FEV}_{1}$ was $12 \mathrm{~mL}$ versus $58 \mathrm{~mL}(P=0.005)$ among patients receiving tiotropium versus placebo (SABAs only) as maintenance therapy. The potential for maintenance bronchodilator therapy to modify the clinical course of COPD has now been examined in a systematic manner in two largescale, long-term clinical studies, ie, UPLIFT ${ }^{\circledR}$ (Understanding Potential Long-term Impacts on Function with Tiotropium $)^{72}$ and TORCH (Towards a Revolution in COPD Health).$^{50}$ Patients in TORCH were randomized to salmeterol and fluticasone propionate (either as monotherapy or in combination), and were permitted use of SABAs and oral corticosteroids to treat exacerbations. Patients in UPLIFT were randomized to tiotropium or placebo and were permitted use of any respiratory medications except inhaled anticholinergics.

The value of long-term maintenance therapy with bronchodilators in COPD is confirmed by the efficacy, mortality, and safety data from UPLIFT and TORCH (Tables 3 and 4, Figure 3). Although UPLIFT did not meet its primary endpoint of pre- and postbronchodilator rate of $\mathrm{FEV}_{1}$ decline, the study did demonstrate significantly greater lung function improvements with tiotropium versus placebo at all time points throughout the trial. ${ }^{72}$ In the TORCH study, lung function was a secondary endpoint, and treatment with salmeterol, fluticasone, or a combination of salmeterol and fluticasone was shown to reduce the rate of lung function decline significantly compared with placebo (Figure $3 \mathrm{a}$, Table 3$)^{{ }^{73}}$ Absolute changes in lung function in UPLIFT and TORCH were determined using different methodologies. For TORCH, the mean postbronchodilator values were determined following salbutamol $400 \mu \mathrm{g}$. It is unclear whether the study drug was administered prior to testing. Study group differences in $\mathrm{FEV}_{1}$ relative to placebo were $42 \mathrm{~mL}$ (salmeterol), $47 \mathrm{~mL}$ (fluticasone), and $92 \mathrm{~mL}$ (combination). Morning predose (trough) values were not measured in TORCH. For
UPLIFT, morning trough differences (tiotropium versus placebo) ranged from 87 to $103 \mathrm{~mL}$, and therefore represent the 24-hour effect of tiotropium. In UPLIFT, both treatment groups were sequentially administered salbutamol $400 \mu \mathrm{g}$ and ipratropium $80 \mu \mathrm{g}$ in addition to the study drug in order to achieve maximal bronchodilation in both groups. Despite both groups having eight actuations of short-acting bronchodilators, treatment group differences in postbronchodilator $\mathrm{FEV}_{1}$ of 47 to $65 \mathrm{~mL}$ were still observed. However, the differences in spirometry protocols render comparisons between the two trials invalid.

The primary endpoint of achieving a significant decrease in mortality among patients treated with combination therapy versus placebo was not reached in TORCH. ${ }^{15}$ However, both TORCH and UPLIFT demonstrated the potential to reduce exacerbation frequency significantly with bronchodilator maintenance therapy (Table 3, Figure 3b). This finding is of considerable importance for all COPD patients with more advanced disease, given recent data indicating heterogeneity in terms of symptomatic recovery from acute COPD exacerbations and the potential of exacerbations to contribute to disease progression. ${ }^{31,34}$ In both the UPLIFT and TORCH studies, statistically significant improvements in QoL (St George's Respiratory Questionnaire total scores) were observed with all active treatments versus placebo (except salmeterol monotherapy in TORCH), although these improvements were not clinically significant (Figure 3c) ${ }^{50,72}$ In UPLIFT, a greater proportion of patients in the tiotropium group than in the placebo group achieved a clinically significant improvement of $\geq 4$ units on the St George's Respiratory Questionnaire total score. ${ }^{72}$

UPLIFT and TORCH have also contributed important information about COPD patients in terms of common comorbidities, smoking status, and concomitant medications, in addition to patient characteristics that might influence the rate of $\mathrm{FEV}_{1}$ decline. For example, a more rapid $\mathrm{FEV}_{1}$ decline was reported in patients with a lower body mass index and in younger ( $<55$ years) compared with older patients, the latter observation being consistent with the recent Framingham Cohort Study reports. ${ }^{13}$ Bronchodilator responsiveness was found to be far more common in COPD than previously recognized and did not impact either the short- or long-term responses to bronchodilator treatment. ${ }^{72,74}$

\section{Treating patients earlier in the disease course}

The potential for disease-course modification with long-term maintenance therapy is perhaps the single most encouraging 


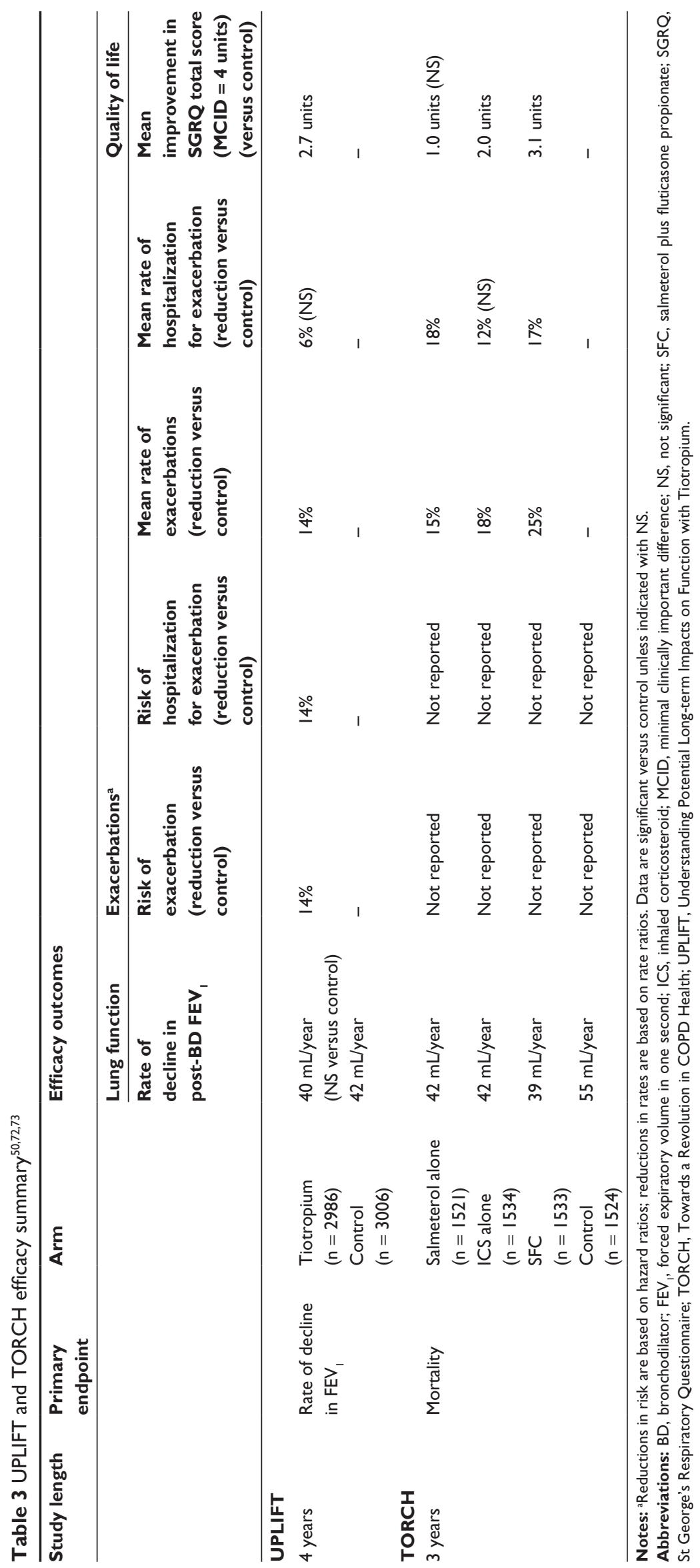


Table 4 UPLIFT and TORCH safety and mortality summary ${ }^{50,72,73}$

\begin{tabular}{|c|c|c|c|c|}
\hline \multirow[t]{2}{*}{ Arm } & \multirow{2}{*}{$\begin{array}{l}\text { Mortality } \\
\text { Reduction in risk of } \\
\text { death (versus control) }^{a}\end{array}$} & \multicolumn{3}{|l|}{ Safety } \\
\hline & & $\begin{array}{l}\text { Adverse events } \\
\text { (\% patients) }\end{array}$ & $\begin{array}{l}\text { Serious adverse events } \\
\text { (\% patients) }\end{array}$ & $\begin{array}{l}\text { Most common adverse events } \\
\text { (incidence rate/year) }^{\mathrm{b}}\end{array}$ \\
\hline \multicolumn{5}{|l|}{ UPLIFT } \\
\hline $\begin{array}{l}\text { Tiotropium } \\
(\mathrm{n}=2986)\end{array}$ & $\begin{array}{l}11 \%(N S)^{c} \\
13 \%^{d}\end{array}$ & 92.6 & 51.6 & COPD exacerbations $(0.38)$ \\
\hline $\begin{array}{l}\text { Control } \\
(\mathrm{n}=3006)\end{array}$ & - & 92.3 & 50.2 & COPD exacerbations $(0.46)$ \\
\hline \multicolumn{5}{|l|}{ TORCH } \\
\hline $\begin{array}{l}\text { Salmeterol alone } \\
(\mathrm{n}=\mid 52 \mathrm{I})\end{array}$ & $12 \%$ (NS) & 90 & 40 & $\begin{array}{l}\text { COPD exacerbations }(0.76) \\
\text { Nasopharyngitis }(0.09) \\
\text { Upper RTI }(0.08) \\
\text { Headache }(0.06)\end{array}$ \\
\hline $\begin{array}{l}\text { ICS alone } \\
(n=1534)\end{array}$ & $-6 \%(N S)$ & 90 & 42 & $\begin{array}{l}\text { COPD exacerbations }(0.78) \\
\text { Nasopharyngitis }(0.10) \\
\text { Upper RTI }(0.09) \\
\text { Pneumonia }(0.07)^{f} \\
\text { Headache }(0.06)\end{array}$ \\
\hline $\begin{array}{l}\text { SFC } \\
(n=1533)\end{array}$ & $18 \%(N S)^{e}$ & 89 & 43 & $\begin{array}{l}\text { COPD exacerbations }(0.67) \\
\text { Upper RTI }(0.1 \mathrm{I}) \\
\text { Nasopharyngitis }(0.10) \\
\text { Pneumonia }(0.07)^{\mathrm{fg}}\end{array}$ \\
\hline $\begin{array}{l}\text { Control } \\
(n=1524)\end{array}$ & - & 90 & 43 & $\begin{array}{l}\text { COPD exacerbations }(0.92) \\
\text { Nasopharyngitis }(0.09) \\
\text { Headache }(0.08)\end{array}$ \\
\hline
\end{tabular}

Notes: aReductions in risk of death were based on hazard ratios; badverse events with incidence rates of $>0.05$ per year; ${ }^{c}$ per protocol analysis versus control. For UPLIFT, this was intent-to-treat +30-day washout and for TORCH this was ITT (no washout); the results were not statistically significant for both studies ( $P=0.09$ for UPLIFT;

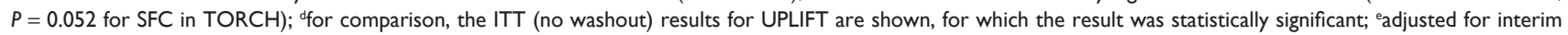
analyses; 'statistically significant increase versus control; 'statistically significant increase versus salmeterol.

Abbreviations: NS, not significant; COPD, chronic obstructive pulmonary disease; RTI, respiratory tract infection; ICS, inhaled corticosteroid; SFC, salmeterol plus fluticasone propionate; ITT, intent to treat; TORCH, Towards a Revolution in COPD Health; UPLIFT, Understanding Potential Long-term Impacts on Function with Tiotropium.

outcome from the UPLIFT and TORCH studies in terms of improving prognosis. To date, only smoking cessation has been shown to change the clinical course of COPD,${ }^{75}$ although long-term oxygen therapy leads to a survival advantage, ${ }^{76}$ and pulmonary rehabilitation has been shown to improve dyspnea and exercise capacity and to reduce exacerbation rate and severity. ${ }^{16}$

Data from both studies indicate the potential to slow the rate of lung function decline and thus change the clinical course of disease for patients diagnosed and treated early. Post hoc and subgroup analyses have shown that initiating maintenance treatment at earlier disease stages can have a greater impact than introducing treatment at later stages with respect to improvements in QoL, reduction in risk/ frequency of exacerbations, improving lung function, and potentially reducing mortality (Table 5). ${ }^{18,19,77,78}$ Both studies demonstrated a slower rate of $\mathrm{FEV}_{1}$ decline compared with placebo for patients with GOLD Stage II disease. In UPLIFT, significant benefits in disease progression and QoL were observed in patients who were maintenance-treatment-naïve at study initiation, ${ }^{78}$ and those aged $\leq 50$ years. ${ }^{77}$ The effects of maintenance pharmacotherapy in early-stage disease need to be rigorously investigated in well designed, prospective studies.

\section{Implications for future COPD management}

In order for the full benefit of the findings from the UPLIFT and TORCH studies to be incorporated into clinical practice, it is necessary to identify early-stage patients. This will require heightened COPD awareness among both patients and physicians. A major barrier to early detection is that patients often do not recognize the early symptoms, or consider them a consequence of aging or smoking.

Spirometry that is performed and interpreted properly is a critical step in the accurate diagnosis of COPD, as is the collection/assessment of patient-reported outcomes and health status, including smoking history, occupation (past and present), daily symptoms (eg, breathlessness, cough, sputum production), activity limitation, and other disease 
A

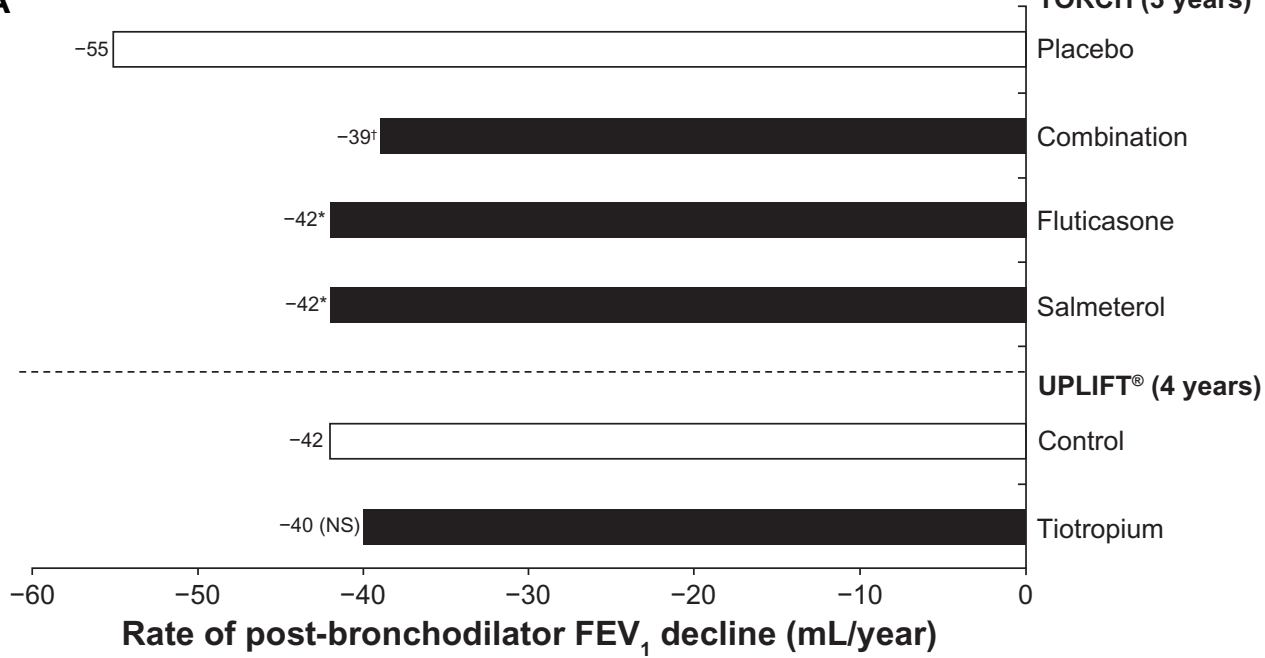

B

TORCH (3 years)

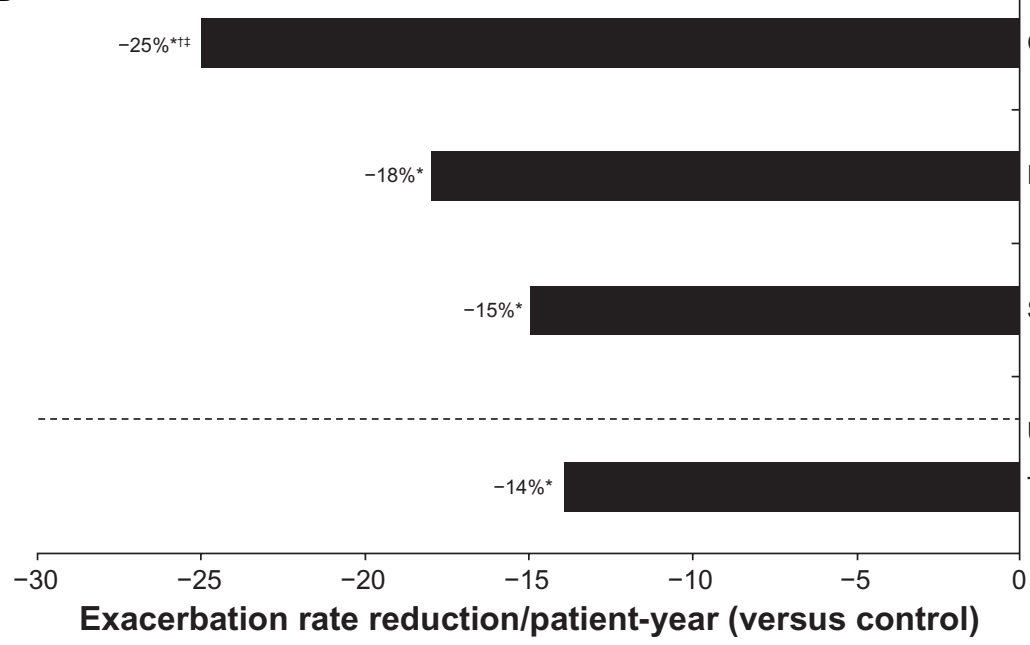

Combination

Fluticasone

Salmeterol

UPLIFT $^{\circledR}$ (4 years)

Tiotropium

C

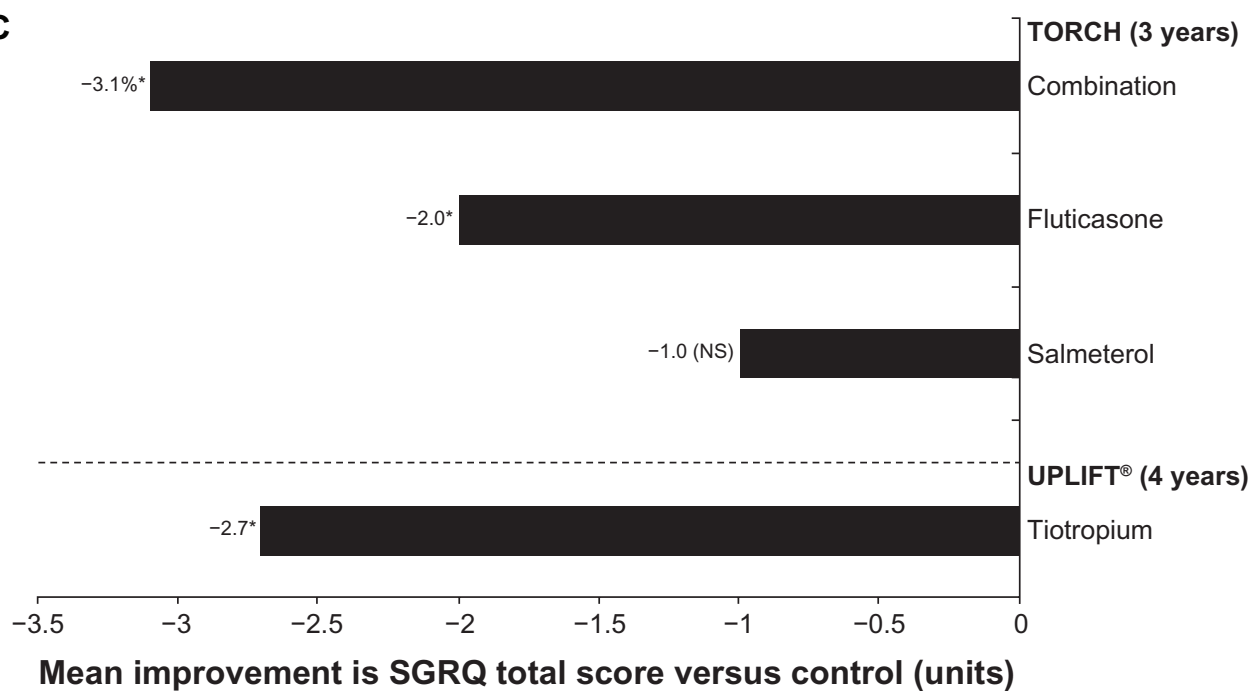

Figure 3 Impact of maintenance bronchodilation on $\mathbf{A}$ ) the rate of decline in lung function, B) exacerbations, and C) quality of life. ${ }^{50,72.73}$

Notes: A) $* P<0.003$ versus placebo; ${ }^{P} f<0.001$ versus; $B$ ) $* P<0.00$ I versus control; $t P<0.02$ versus salmeterol; $¥ P<0.02$ versus fluticasone; C) $* P<0.00$ I versus control. Abbreviation: TORCH, Towards a Revolution in COPD Health; UPLIFT, Understanding Potential Long-term Impacts on Function with Tiotropium; FevI, forced expiratory volume in one second; SGRQ, St George's Respiratory Questionnaire; NS, nonsignificant versus control. 


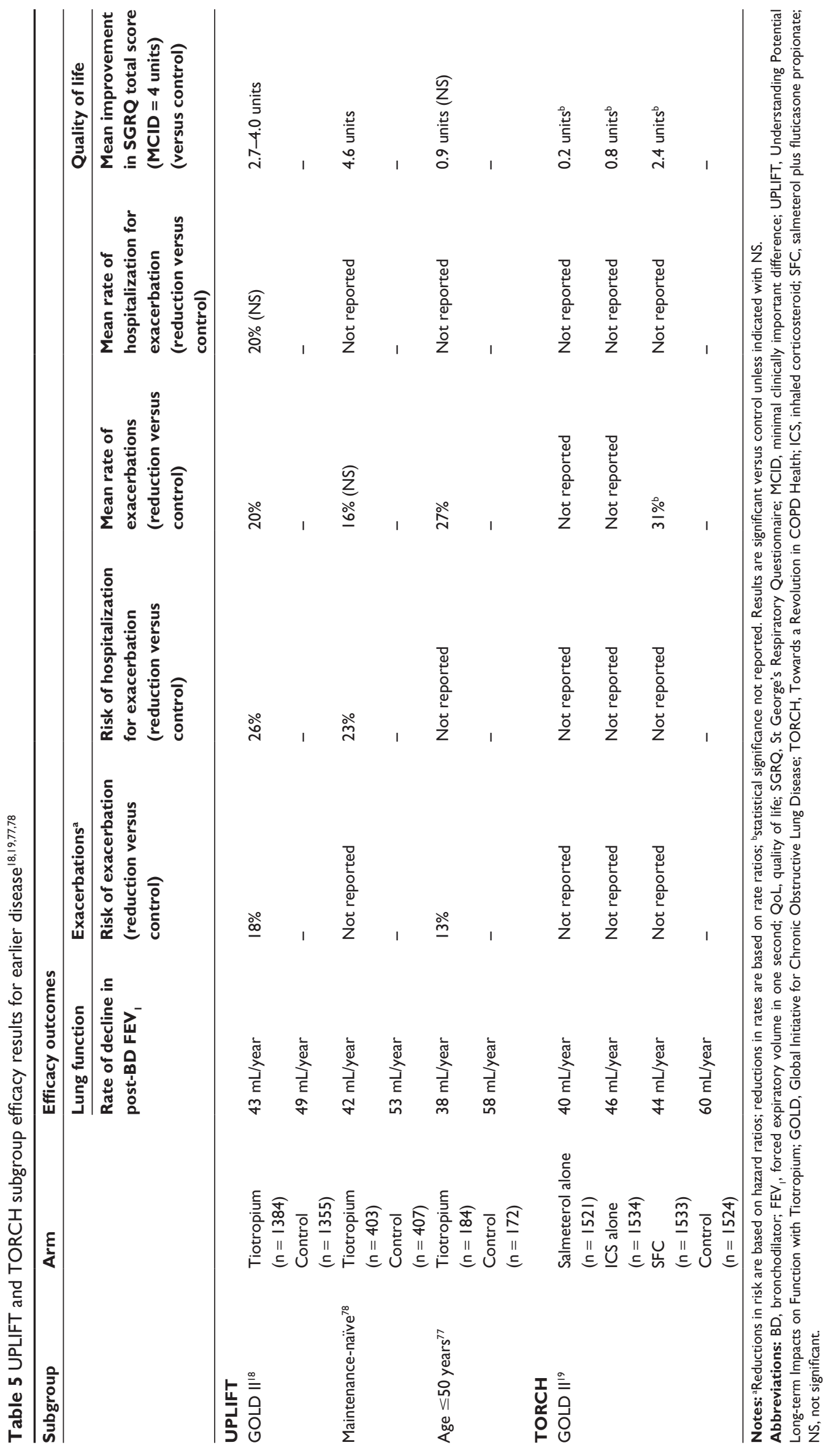


manifestations. Improved identification of patients at risk for developing COPD, based on recognized risk factors and symptoms, is required to enable early diagnosis and to initiate prompt maintenance treatment. Diagnostic tools and questionnaires (eg, St George's Respiratory Questionnaire, Chronic Respiratory Questionnaire) can facilitate clinical assessment; however, their length precludes practical application in everyday practice. Two shortened and simplified COPD screening tools may be more suited to clinical settings and for the general public, ie, the COPD Assessment Test ${ }^{79}$ and the self-administered COPD Population Screener ${ }^{\mathrm{TM}} .^{80}$ These tools may help to identify patients likely to have COPD, but further evaluation and validation is required to confirm their usefulness in clinical practice.

Programs to educate both physicians and patients are also necessary to increase vigilance for early signs and symptoms, including increased recognition that COPD is not restricted to the elderly but can also affect younger people in their $30 \mathrm{~s}$ and $40 \mathrm{~s},{ }^{81}$ and removal of the nihilistic attitude that COPD is a self-inflicted disease. Improved adherence to treatment guidelines, including correct implementation of spirometry, is also required.

\section{Conclusion}

The emergence of scientific evidence from multiple sources, including large clinical trials, has expanded our knowledge of COPD and fuelled a shift in our understanding of lung function decline and disease progression. Coupled with the emergence of a range of new drug treatments with differing mechanisms of action targeting different physiologic aspects of the disease, the first decade of this new century has become an exciting period in COPD management. The current challenge is to apply our understanding of disease processes to the design of optimal treatment algorithms for maintenance therapy, encompassing both established and emerging drug treatments. Landmark clinical trial data reinforce when foundation maintenance therapy should be introduced for symptomatic patients with COPD and its long-term health benefits. Finally, emerging evidence supports the early introduction of pharmacotherapies that relieve breathlessness, with the aim of slowing lung function decline and reducing the risk of acute exacerbations. However, further studies are required before evidence-based guidelines are able to assess adequately the potential of treatment for early-stage disease.

\section{Disclosure}

Writing and editorial assistance was provided by PAREXEL MMS writers Claire Scarborough and Natalie Barker. Those services were contracted by Boehringer Ingelheim $\mathrm{GmbH}$ and Pfizer Inc. The authors received no financial compensation related to the development of the manuscript.

\section{References}

1. Global Initiative for Chronic Obstructive Lung Disease. Global strategy for the diagnosis, management, and prevention of chronic obstructive pulmonary disease. Updated 2009. Available from: www.goldcopd.com. Accessed 2010 May 12.

2. Buist AS, Vollmer WM, McBurnie MA. Worldwide burden of COPD in high- and low-income countries. Part I. The burden of obstructive lung disease (BOLD) initiative. Int J Tuberc Lung Dis. 2008;12: 703-708.

3. Mannino DM, Buist AS. Global burden of COPD: Risk factors, prevalence, and future trends. Lancet. 2007;370:765-773.

4. Mathers CD, Loncar D. Projections of global mortality and burden of disease from 2002 to 2030. PLoS Med. 2006;3:e442.

5. Sullivan SD, Ramsey SD, Lee TA. The economic burden of COPD. Chest. 2000;117:S5-S9.

6. Shavelle RM, Paculdo DR, Kush SJ, Mannino DM, Strauss DJ. Life expectancy and years of life lost in chronic obstructive pulmonary disease: Findings from the NHANES III Follow-up Study. Int J Chron Obstruct Pulmon Dis. 2009;4:137-148.

7. Hogg JC. Pathophysiology of airflow limitation in chronic obstructive pulmonary disease. Lancet. 2004;364:709-721.

8. Cooper CB, Dransfield M. Primary care of the patient with chronic obstructive pulmonary disease - Part 4: Understanding the clinical manifestations of a progressive disease. Am J Med. 2008;121 7 Suppl:S33-S45.

9. Wouters EF. Economic analysis of the Confronting COPD survey: An overview of results. Respir Med. 2003;97 Suppl C:S3-S14.

10. Chatila WM, Thomashow BM, Minai OA, Criner GJ, Make BJ. Comorbidities in chronic obstructive pulmonary disease. Proc Am Thorac Soc. 2008;5:549-555.

11. Lindberg A, Jonsson AC, Ronmark E, Lundgren R, Larsson LG, Lundbäck B. Prevalence of chronic obstructive pulmonary disease according to BTS, ERS, GOLD and ATS criteria in relation to doctor's diagnosis, symptoms, age, gender, and smoking habits. Respiration. 2005;72:471-479.

12. British Lung Foundation. Invisible lives. Chronic obstructive lung disease (COPD) - finding the missing millions. Available from: http:// www.lunguk.org. Accessed 2010 May 12.

13. Kohansal R, Martinez-Camblor P, Agusti A, Buist AS, Mannino DM, Soriano JB. The natural history of chronic airflow obstruction revisited: An analysis of the Framingham offspring cohort. Am J Respir Crit Care Med. 2009;180:3-10.

14. Celli BR, MacNee W; ATS/ERS Task Force. Standards for the diagnosis and treatment of patients with COPD: A summary of the ATS/ERS position paper. Eur Respir J. 2004;23:932-946.

15. O'Donnell DE, Aaron S, Bourbeau J, et al. Canadian Thoracic Society recommendations for management of chronic obstructive pulmonary disease - 2007 update. Can Respir J. 2007;14 Supp1 B:B5-B32.

16. Halpin D. NICE guidance for COPD. Thorax. 2004;59:181-182.

17. Fletcher $\mathrm{C}$, Peto R. The natural history of chronic airflow obstruction. Br Med J. 1977;1:1645-1648.

18. Decramer M, Celli B, Kesten S, Lystig T, Mehra S, Tashkin DP; UPLIFT investigators. Effect of tiotropium on outcomes in patients with moderate chronic obstructive pulmonary disease (UPLIFT): A prespecified subgroup analysis of a randomised controlled trial. Lancet. 2009;374:1171-1178.

19. Jenkins CR, Jones PW, Calverley PM, et al. Efficacy of salmeterol/ fluticasone propionate by GOLD stage of chronic obstructive pulmonary disease: Analysis from the randomised, placebo-controlled TORCH study. Respir Res. 2009;10:59.

20. Mannino DM, Watt G, Hole D, et al. The natural history of chronic obstructive pulmonary disease. Eur Respir J. 2006;27:627-643. 
21. Tashkin DP. Frequent exacerbations of chronic obstructive pulmonary disease - a distinct phenotype? New Engl J Med. 2010;363:1183-1184.

22. Hurst JR, Vestbo J, Anzueto A, et al. Susceptibility to exacerbation in chronic obstructive pulmonary disease. New Engl J Med. 2010;363:1128-1138.

23. Bridevaux PO, Gerbase MW, Probst-Hensch NM, Schindler C, Gaspoz JM, Rochat T. Long-term decline in lung function, utilisation of care and quality of life in modified GOLD stage 1 COPD. Thorax. 2008;63:768-774.

24. Ofir D, Laveneziana P, Webb KA, Lam YM, O’Donnell DE. Mechanisms of dyspnea during cycle exercise in symptomatic patients with GOLD stage I chronic obstructive pulmonary disease. Am J Respir Crit Care Med. 2008;177:622-629.

25. Troosters T, Sciurba F, Battaglia S, et al. Physical inactivity in patients with COPD, a controlled multi-center pilot-study. Respir Med. 2010; 104:1005-1011.

26. Garcia-Aymerich J, Serra I, Gómez FP, et al. Physical activity and clinical and functional status in COPD. Chest. 2009;136: 62-70.

27. Donaldson GC, Seemungal TAR, Bhowmik A, Wedzicha JA. Relationship between exacerbation frequency and lung function decline in chronic obstructive pulmonary disease. Thorax. 2002;57: 847-852.

28. Makris D, Moschandreas J, Damianaki A, et al. Exacerbations and lung function decline in COPD: New insights in current and ex-smokers. Respir Med. 2007;101:1305-1312.

29. Paggiaro PL, Dahle R, Bakran I, et al. Multicentre randomised placebocontrolled trial of inhaled fluticasone propionate in patients with chronic obstructive pulmonary disease. International COPD Study Group. Lancet. 1998;351:773-780.

30. Gompertz S, Bayley DL, Hill SL, Stockley RA. Relationship between airway inflammation and the frequency of exacerbations in patients with smoking related COPD. Thorax. 2001;56:36-41.

31. Perera WR, Hurst JR, Wilkinson TM, et al. Inflammatory changes, recovery and recurrence at COPD exacerbation. Eur Respir J. 2007; 29:527-534

32. Pitta F, Troosters T, Probst VS, Spruit MA, Decramer M, Gosselink R. Physical activity and hospitalization for exacerbation of COPD. Chest. 2006;129:536-544.

33. Hurst JR, Donaldson GC, Quint JK, Goldring JJ, Baghai-Ravary R, Wedzicha JA. Temporal clustering of exacerbations in chronic obstructive pulmonary disease. Am J Respir Crit Care Med. 2009; 179:369-374.

34. Tsai CL, Rowe BH, Camargo CA, Jr. Factors associated with short-term recovery of health status among emergency department patients with acute exacerbations of chronic obstructive pulmonary disease. Qual Life Res. 2009;18:191-199.

35. Groenewegen KH, Dentener MA, Wouters EF. Longitudinal follow-up of systemic inflammation after acute exacerbations of COPD. Respir Med. 2007;101:2409-2415.

36. Glaab T, Banik N, Rutschmann OT, Wencker M. National survey of guideline-compliant COPD management among pneumologists and primary care physicians. COPD. 2006;3:141-148.

37. Rutschmann OT, Janssens JP, Vermeulen B, Sarasin FP. Knowledge of guidelines for the management of COPD: A survey of primary care physicians. Respir Med. 2004;98:932-937.

38. Ta M, George J. Management of COPD in Australia after the publication of national guidelines. Intern Med J. [Epub ahead of print].

39. Derom E, van Weel C, Liistro G, et al. Primary care spirometry. Eur Respir J. 2008;31:197-203.

40. Lusuardi M, De Benedetto F, Paggiaro P, et al. A randomized controlled trial on office spirometry in asthma and COPD in standard general practice: Data from spirometry in asthma and COPD: A comparative evaluation Italian study. Chest. 2006;129: 844-852.
41. Arne M, Lisspers K, Ställberg B, Boman G, et al. How often is diagnosis of COPD confirmed with spirometry? Respir Med. 2010;104: $550-556$.

42. Jones RC, Dickson-Spillmann M, Mather MJ, Marks D, Shackell BS. Accuracy of diagnostic registers and management of chronic obstructive pulmonary disease: The Devon primary care audit. Respir Res. 2008; 9:62.

43. Donohue JF, van Noord JA, Bateman ED, et al. A 6-month, placebocontrolled study comparing lung function and health status changes in COPD patients treated with tiotropium or salmeterol. Chest. 2002; 122:47-55.

44. Brusasco V, Hodder R, Miravitlles M, Korducki L, Towse L, Kesten S. Health outcomes following treatment for six months with once daily tiotropium compared with twice daily salmeterol in patients with COPD. Thorax. 2006;61:91.

45. Vogelmeier C, Kardos P, Harari S, Gans SJ, Stenglein S, Thirlwell J. Formoterol mono- and combination therapy with tiotropium in patients with COPD: A 6-month study. Respir Med. 2008;102:1511-1520.

46. van Noord JA, Aumann JL, Janssens E, et al. Comparison of tiotropium once daily, formoterol twice daily and both combined once daily in patients with COPD. Eur Respir J. 2005;26:214-222.

47. Vincken W. Bronchodilator treatment of stable COPD: Long-acting anticholinergics. Eur Respir Rev. 2005;14:23-31.

48. Welte T, Miravitlles M, Hernandez P, et al. Efficacy and tolerability of budesonide/formoterol added to tiotropium in patients with chronic obstructive pulmonary disease. Am J Respir Crit Care Med. 2009; 180:741-750.

49. Cazzola M, Dahl R. Inhaled combination therapy with longacting beta 2-agonists and corticosteroids in stable COPD. Chest. 2004;126:220-237.

50. Calverley PM, Anderson JA, Celli B, et al. TORCH investigators. Salmeterol and fluticasone propionate and survival in chronic obstructive pulmonary disease. $N$ Engl J Med. 2007;356:775-789.

51. Wedzicha JA, Calverley PM, Seemungal TA, Hagan G, Ansari Z, Stockley RA; INSPIRE Investigators. The prevention of chronic obstructive pulmonary disease exacerbations by salmeterol/fluticasone propionate or tiotropium bromide. Am J Respir Crit Care Med. 2008; 177:19-26.

52. Singh D, Brooks J, Hagan G, Cahn A, O'Connor BJ. Superiority of "triple" therapy with salmeterol/fluticasone propionate and tiotropium bromide versus individual components in moderate to severe COPD. Thorax. 2008;63:592-598.

53. Perng DW, Wu CC, Su KC, Lee YC, Perng RP, Tao CW. Additive benefits of tiotropium in COPD patients treated with long-acting beta agonists and corticosteroids. Respirology. 2006;11:598-602.

54. Cosio BG, Iglesias A, Rios A, et al. Low-dose theophylline enhances the anti-inflammatory effects of steroids during exacerbations of COPD. Thorax. 2009;64:424-429.

55. Poole PJ, Black PN. Mucolytic agents for chronic bronchitis or chronic obstructive pulmonary disease. Cochrane Database Syst Rev. 2003;3:CD001287.

56. Stey C, Steurer J, Bachmann S, Medici TC, Tramèr MR. The effect of oral N-acetylcysteine in chronic bronchitis: A quantitative systematic review. Eur Respir J. 2000;16:253-262.

57. Zheng JP, Kang J, Huang SG, et al. Effect of carbocisteine on acute exacerbation of chronic obstructive pulmonary disease (PEACE Study): A randomised placebo-controlled study. Lancet. 2008;371: 2013-2018.

58. Decramer M, Rutten-van Mölken M, Dekhuijzen PN, et al. Effects of $\mathrm{N}$-acetylcysteine on outcomes in chronic obstructive pulmonary disease (Bronchitis Randomized on NAC Cost-Utility Study, BRONCUS): A randomised placebo-controlled trial. Lancet. 2005;365: 1552-1560.

59. Vestbo J, Anderson JA, Calverley PM, et al. Adherence to inhaled therapy, mortality and hospital admission in COPD. Thorax. 2009; 64:939-943. 
60. Bateman ED. Improving inhaler use in COPD and the role of patient preference. Eur Respir Rev. 2005;14:85-88.

61. Laghi F, Adiguzel N, Tobin MJ. Endocrinological derangements in COPD. Eur Respir J. 2009;34:975-996.

62. Decramer M, Rennard S, Troosters T, et al. COPD as a lung disease with systemic consequences - clinical impact, mechanisms, and potential for early intervention. COPD. 2008;5:235-256.

63. Donohue JF, Fogarty C, Lötvall J, et al; INHANCE study investigators. Once-daily bronchodilators for chronic obstructive pulmonary disease: Indacaterol versus tiotropium. Am J Respir Crit Care Med. 2010;182:155-162.

64. Dahl R, Chung KF, Buhl R, et al; INVOLVE (INdacaterol: Value in COPD: Longer Term Validation of Efficacy and Safety) Study Investigators. Efficacy of a new once-daily long-acting inhaled beta2agonist indacaterol versus twice-daily formoterol in COPD. Thorax. 2010;65:473-479.

65. Soto FJ, Hanania NA. Selective phosphodiesterase-4 inhibitors in chronic obstructive lung disease. Curr Opin Pulm Med. 2005;11: 129-134.

66. Calverley PM, Rabe KF, Goehring UM, Kristiansen S, Fabbri LM, Martinez FJ; M2-124 and M2-125 study groups. Roflumilast in symptomatic chronic obstructive pulmonary disease: Two randomised clinical trials. Lancet. 2009;374:685-694.

67. Rabe KF, Bateman ED, O’Donnell D, Witte S, Bredenbröker D, Bethke TD. Roflumilast - an oral anti-inflammatory treatment for chronic obstructive pulmonary disease: A randomised controlled trial. Lancet. 2005;366:563-571.

68. Fabbri LM, Calverley PM, Izquierdo-Alonso JL, Brose M, Martinez FJ, Rabe KF; M2-127 and M2-128 study groups. Roflumilast in moderateto-severe chronic obstructive pulmonary disease treated with longacting bronchodilators: Two randomised clinical trials. Lancet. 2009; 374:695-703.

69. European Medicines Agency and Committee for Medicinal Products for Human Use. Summary of opinion (initial authorisation). Daxas. Roflumilast. Available from: http://www.ema.europa.eu. Accessed 2010 May 12.

70. Chanez $\mathrm{P}$, et al. Aclidinium bromide provides long-acting bronchodilation in patients with COPD. Pulm Pharmacol Ther. 2010;23:15-21.
71. Anzueto A, Tashkin D, Menjoge S, Kesten S. One-year analysis of longitudinal changes in spirometry in patients with COPD receiving tiotropium. Pulm Pharmacol Ther. 2005;18:75-81.

72. Tashkin DP, Celli B, Senn S, et al; UPLIFT ${ }^{\circledR}$ Study Investigators. A 4-year trial of tiotropium in chronic obstructive pulmonary disease. N Engl J Med. 2008;359:1543-1554.

73. Celli BR, Thomas NE, Anderson JA, et al. Effect of pharmacotherapy on rate of decline of lung function in chronic obstructive pulmonary disease: Results from the TORCH study. Am J Respir Crit Care Med. 2008; 178:332-338.

74. Hanania N, Kesten S, Celli B, et al. Acute bronchodilator response does not predict health outcomes in patients with COPD treated with tiotropium. Eur Respir J. 2009;34 Suppl 53:S777.

75. Anthonisen NR, Connett JE, Kiley JP, et al. Effects of smoking intervention and the use of an inhaled anticholinergic bronchodilator on the rate of decline of $\mathrm{FEV}_{1}$. The Lung Health Study. JAMA. 1994; 272:1497-1505

76. Long term domiciliary oxygen therapy in chronic hypoxic cor pulmonale complicating chronic bronchitis and emphysema. Report of the Medical Research Council Working Party. Lancet. 1981;1:681-686.

77. Morice AH, Celli B, Kesten S, Lystig T, Tashkin D, Decramer M. COPD in young patients: A pre-specified analysis of the four-year trial of tiotropium (UPLIFT). Respir Med. 2010;104:1659-1667.

78. Troosters T, Celli B, Lystig T, et al. Tiotropium as a first maintenance drug in COPD: Secondary analysis of the UPLIFT ${ }^{\circledR}$ trial. Eur Respir J. 2010;36:65-73.

79. Jones P, Harding G, Wiklund I, Berry P, Leidy N. Improving the process and outcome of care in COPD: Development of a standardised assessment tool. Prim Care Respir J. 2009;18:208-215.

80. Martinez FJ, Raczek AE, Seifer FD, et al. Development and initial validation of a self-scored COPD Population Screener Questionnaire (COPD-PS). COPD. 2008;5:85-95.

81. de Marco R, Accordini S, Cerveri I, Corsico A, Sunyer J, Neukirch F, et al. An international survey of chronic obstructive pulmonary disease in young adults according to GOLD stages. Thorax. 2004;59:120-125.
International Journal of COPD

\section{Publish your work in this journal}

The International Journal of COPD is an international, peer-reviewed journal of therapeutics and pharmacology focusing on concise rapid reporting of clinical studies and reviews in COPD. Special focus is given to the pathophysiological processes underlying the disease, intervention programs, patient focused education, and self management protocols.

\section{Dovepress}

This journal is indexed on PubMed Central, MedLine and CAS. The manuscript management system is completely online and includes a very quick and fair peer-review system, which is all easy to use. Visit http://www.dovepress.com/testimonials.php to read real quotes from published authors. 